\title{
GAMBARAN FAKTOR-FAKTOR PENGHAMBAT PEMBERIAN ASI EKSKLUSIF PADA IBU MENYUSUI BAYI USIA 0-6 BULAN DI WILAYAH KERJA PUSKESMAS MASSENGA
}

\author{
LINA FITRIANI
}

Latar belakang : ASI eksklusif merupakan nutrisi yang terbaik pada 6 bulan pertama kehidupan bayi dan terpenting untuk mencapai tumbuh kembang yang optimal. Masih rendahnya cakupan pemberian ASI eksklusif antara lain dapat disebabkan beberapa faktor yaitu perubahan sosial budaya, kekurangtahuan ibu terhadap manfaat pemberian ASI dan rendahnya tingkat pendidikan ibu.

Tujuan penelitian : adalah untuk mengetahui faktor-faktor penghambat pemberian ASI eksklusif pada ibu menyusui bayi usia 0-6 bulan di wilayah kerja Puskesmas Massengga. Metode penelitian : merupakan penelitian yang bersifat deskriptif, subjek penelitiannya yaitu ibu menyusui di Puskesmas Massenga. Sedangkan objek penelitiannya adalah gambaran faktor-faktor penghambat pemberian ASI eksklusif pada ibu menyusui bayi usia 0-6 bulan. Jumlah sampel sebanyak 78 orang dengan penentuan sampel menggunakan multistage random sampling. Alat pengambilan data yang digunakan adalah lembar kuesioner yang terdiri dari 20 pertanyaan mengenai ASI eksklusif.

Kata Kunci : faktor-faktor penghambat pemberian ASI eksklusif

\section{PENDAHULUAN}

Pada masa modern seperti ini, sebagian ibu merasa enggan menyusui anaknya. Sebenarnya gejala tersebut sudah membudaya sejak sekian lama, terutama di kota-kota besar, semula hal itu dilakukan oleh para ibu di Eropa dan Amerika pada awal abad ke 20. Tindakan ini menyebabkan anak mudah terserang penyakit karena daya tahannya lemah. Ternyata fenomena yang menunjukkan bahwa sebagian ibu tidak menyusui anaknya tidak hanya terjadi di negara-negara maju, tetapi juga di negara-negara berkembang.

Pada masa lima tahun pertama kehidupan, pertumbuhan mental dan intelektual anak sangat di tentukan oleh asupan makanan yang diberikan. Salah satu asupan makanan bayi yang sangat berkualitas dan tidak dapat digantikan oleh makanan lain adalah ASI Eksklusif. ASI eksklusif merupakan nutrisi yang terbaik bagi bayi dan terpenting untuk mencapai tumbuh kembang yang optimal.
Pemberian ASI eksklusif akan membantu pertumbuhan yang adekuat dalam 6 bulan pertama untuk mencapai status gizi yang baik.

Air Susu Ibu (ASI) Eksklusif adalah pemberian ASI tanpa makanan dan minuman lain. ASI Eksklusif dianjurkan sampai 6 bulan pertama kehidupan (Depkes RI, 2005). Manfaat dari pemberian ASI eksklusif sangat luar biasa. Bagi bayi, ASI eksklusif adalah makanan dengan kandungan gizi yang paling sesuai untuk kebutuhan bayi, melindungi dari berbagai infeksi dan memberikan hubungan kasih sayang yang mendukung semua aspek perkembangan bayi, termasuk kesehatan dan kecerdasan bayi. Bagi ibu, memberikan ASI secara eksklusif dapat mengurangi pendarahan pada saat persalinan, menunda kesuburan dan meringankan beban ekonomi (Roesli, 2008).

Program Peningkatan Penggunaan Air Susu Ibu (PP-ASI) khususnya ASI 
Eksklusif merupakan program prioritas pemerintah, karena manfaatnya yang luas terhadap status gizi dan kesehatan bayi. Peraturan Pemerintah Indonesia Nomor 33 tahun 2012 juga menjelaskan kewajiban bagi setiap ibu untuk memberikan ASI eksklusif. Program ini berkaitan dengan Deklarasi Innocenti (Italia) tahun 1990 tentang perlindungan, promosi, dan dukungan terhadap penggunaan ASI, disepakati untuk pencapaian pemberian ASI Eksklusif sebesar $80 \%$ pada tahun 2000. Salah satu kesepakatan Konferensi Tingkat Tinggi Kesejahteraan Anak tahun 1990 adalah semua keluarga mengetahui pentingnya mendukung wanita memberikan ASI saja untuk 4 sampai 6 bulan pertama kehidupan anak. Untuk mendukung pemberian ASI Eksklusif di Indonesia, pada tahun 1990 pemerintah mencanangkan Gerakan Nasional Peningkatan Pemberian ASI (PP-ASI) yang salah satu tujuannya adalah untuk membudayakan perilaku menyusui secara eksklusif kepada bayi dari lahir sampai dengan berumur 4 bulan. Pada tahun 2004, sesuai dengan anjuran badan kesehatan dunia (WHO), pemberian ASI Eksklusif ditingkatkan menjadi 6 bulan. (KEPMENKES RI NO. 450/MENKES/SK/VI/2004.

Menurut WHO-UNICEF pada tahun 2002 dalam Global Strategy for Infant and Young Child Feeding menerapkan cara pemberian makan pada bayi yang baik dan benar yaitu menyusui bayi secara eksklusif sejak lahir sampai dengan umur 6 bulan dan meneruskan menyusui anak sampai umur 24 bulan dan mulai umur 6 bulan, bayi mendapat Makanan Pendamping ASI (MP-ASI). Data Susenas (2007-2008) cakupan pemberian ASI eksklusif pada bayi 0-6 bulan di Indonesia menunjukkan penurunan dari 62,2 \% (2007) menjadi $56,2 \%$ (2008). Sedangkan cakupan pemberian ASI eksklusif pada bayi sampai 6 bulan turun dari 28,6\% (2007) menjadi 24,3 \% (2008). Sementara jumlah bayi di bawah enam bulan yang diberi susu formula meningkat dari $16,7 \%$ pada 2002 menjadi 27,9 \% pada 2003 (Riskesdas, 2010).

Masih rendahnya cakupan pemberian ASI antara lain dapat disebabkan beberapa faktor : perubahan sosial budaya, faktor psikologis, faktor fisik ibu, faktor kurangnya petugas kesehatan, meningkatnya promosi PASI, dan penerangan yang salah dari petugas kesehatan. Tidak adanya dukungan dari keluarga, terutama suami dalam memberikan ASI, kekurangtahuan ibu terhadap manfaat pemberian ASI dan rendahnya tingkat pendidikan ibu dapat menjadi penyebab rendahnya tingkat pemberian ASI eksklusif ini (Seswita, 2005).

Berdasarkan penelitian oleh Rahmawati tahun 2007 menunjukkan bahwa faktor paling dominan yang mempengaruhi pemberian ASI eksklusif adalah ststus pekerjaan dengan $\mathrm{p}=0,008$ dan $\mathrm{OR}=4,137$ yang menandakan bahwa ibu yang tidak bekerja berpeluang memberikan ASI ekskusif pada bayinya 4 kali dibanding ibu yang bekerja. Faktor-faktor yang berpengaruh terhadap pemberian ASI eksklusif pada ibu menyusui di kelurahan Pedalangan Kecamatan Banyumanik Kota Semarang adalah usia ibu, status pekerjaan, urutan kelahiran bayi, dukungan petugas kesehatan dan faktor yang paling dominan adalah status pekerjaan.

Berdasarkan hasil penelitian Tarigan pada tahun 2012 antara lain faktor penghambat dalam pemberian ASI Eksklusif kepada bayi adalah pengetahuan, sikap, dan perilaku ibu, di mana sebagian besar ibu masih belum paham tentang manfaat pemberian ASI Eksklusif. Faktor 
pekerjaan, pendidikan, dan balita juga sebagai pemicu penghambat untuk pemberian ASI Eksklusif kepada bayinya.

Berdasarkan hasil penelitian oleh Suprijati tahun 2013 menunjukkan bahwa semua menyatakan faktor umur, pendidikan, pekerjaan tidak mengganggu aktifitas menyusui bayi, semua informan mengatakan mulanya mereka memberikan ASI setelah kelahiran bayinya namun karena kendala ASI tidak lancar dan tidak mau repot, rewel anaknya menangis akhirnya mereka memberikan susu botol. Menurut informan sebetulnya mereka tahu tentang pentingnya memberikan ASI dibanding susu formula, namun mereka merasa khawatir bila bayinya tidak diberi susu botol maka bayinya tidak bisa menjadi gemuk, atau tidak bisa cepat naik berat badannya seperti yang mereka harapkan.

Bayi yang diberikan susu selain ASI, mempunyai resiko 17 kali lebih besar mengalami diare, dan 3 sampai 4 kali lebih besar kemungkinan terkena ISPA dibandingkan dengan bayi yang mendapat ASI. (WHO 2000).

Agar menyusui dapat berhasil dengan baik diperlukan dukungan aktif para ibu selama hamil sampai anak usia minimal 2 tahun. Dukungan ini bukan hanya dari keluarga dan masyarakat melainkan juga dari

\section{METODE PENELITIAN}

\section{Jenis dan Metode Penelitian}

Jenis penelitian ini adalah penelitian dengan pendekatan studi kasus deskritif kuantitatif, yaitu suatu metode penelitian yang menggambarkan, menguraikan dan melukiskan suatu keadaan yang sebenarnya sedang berlansung pada saat sekarang berdasarkan atas perhitungan persentase, rata-rata dan perhitungan statistik lainnya dengan kata lain penelitian kuantitatif melibatkan diri pada perhitungan atau seluruh sistem pelayanan kesehatan. Lebih - lebih petugas kesehatan dan kader kesehatan di posyandu sebaiknya tidak berhenti dalam memberikan penyuluhan dan pendidkan kesehatan tentang pentingnya pemberian ASI ekslusif untuk pertumbuhan dan perkembangan bayi sampai usia 4-6 bulan. Disamping itu perlu adanya penyebaran leaflet dan informasi seputar pentingnya ASI baik di media cetak maupun media elektronik yang terjangkau oleh masyarakat.

Berdasarkan studi pendahuluan yang dilakukan oleh peneliti di Puskesmas Massengga dengan cara melakukan wawancara pada $10 \mathrm{ibu}$ menyusui , hanya 3 orang ibu menyusui yang memberikan ASI eksklusif dan 7 orang lainnya memberikan susu formula. Alasan ibu tidak memberikan ASI eksklusif karena faktor ibu bekerja, minimnya pengeluaran ASI, kurangnya pengetahuan tentang manfaat ASI, puting susu ibu yang tenggelam serta rasa kekhawatiran akan berat badan bayi yang tidak sesuai dengan keinginan.

Berdasarkan uraian di atas, penulis tertarik melakukan penelitian tentang gambaran faktor-faktor penghambat pemberian ASI eksklusif pada ibu menyusui bayi usia 0-6 bulan di wilayah kerja Puskesmas Massengga.

angka atau kuantitas. Rancangan dalam penelitian ini adalah dengan menggunakan metode pendekatan Cross Sectional yaitu variabel sebab atau risiko dan akibat atau kasus yang terjadi pada objek penelitian diukur atau dikumpulkan secara simultan (dalam waktu yang bersamaan).

Penelitian ini dilakukan di wilayah kerja puskesmas Massenga pada bulan Oktober Tahun 2017.

\section{Populasi dan Sampel}


Populasi dalam penelitian ini adalah ibu menyusui pada bulan JanuariSeptember 2017 yaitu sebanyak 353 orang ibu menyusui yang tercatat pada

HASIL DAN PEMBAHASAN

\section{Hasil Penelitian}

rekam medic di Puskesmas Massengga. Serta jumlah sampel sebesar 78 orang.

Tabel 4.1

Distribusi Frekuensi Responden Menurut Kelompok Umur di Posyandu Wilayah kerja Puskesmas Massenga

\begin{tabular}{|l|l|l|l|}
\hline No & Pekerjaan & Frekuensi & Persentase (\%) \\
\hline 1 & $<20$ & 13 & 16.67 \\
2 & $20-35$ & 56 & 71.79 \\
3 & $>35$ & 9 & 11.54 \\
\hline Jumlah & $\mathbf{7 8}$ & $\mathbf{1 0 0}$ \\
\hline
\end{tabular}

Berdasarkan tabel 4.1 tentang umur responden, dimana hasil penelitian menunjukkan bahwa dari 78 responden yang berusia $<20$ tahun sebanyak 13 responden atau (16.67
$\%$ ), yang berusia 20-35 tahun sebanyak 56 responden atau (71.79 $\%$ ), dan yang berusia > 35 tahun sebanyak 9 responden atau ( $11.54 \%)$.

Tabel 4.2

\section{Distribusi Frekuensi Tingkat Pengetahuan Responden}

\begin{tabular}{|l|l|l|l|}
\hline No & Kategori & Frekuensi & Persentase (\%) \\
\hline 1 & Baik & 20 & 25.64 \\
2 & Cukup & 55 & 70.51 \\
3 & Kurang & 3 & 3.85 \\
\hline \multicolumn{2}{|c|}{ Jumlah } & $\mathbf{7 8}$ & $\mathbf{1 0 0}$ \\
\hline
\end{tabular}

Berdasarkan Tabel 4.2 menunjukkan bahwa pengetahuan responden tentang ASI Eksklusif, dimana hasil penelitian menunjukkan bahwa dari 78 responden yang memperoleh kriteria baik sebanyak
20 responden atau $(25.64 \%)$, yang memperoleh kriteria cukup sebanyak 55 responden atau (70.51\%), dan yang mempunyai kriteria kurang sebanyak 3 responden atau $(3.85 \%)$.

Tabel 4.3

Distribusi Frekuensi Tingkat Pekerjaan

\begin{tabular}{|l|l|l|l|}
\hline No & Kategori & Frekuensi & Persentase (\%) \\
\hline
\end{tabular}




\begin{tabular}{|l|l|l|l|}
1 & Bekerja & 41 & 52.56 \\
2 & Tidak bekerja & 37 & 47.44 \\
\hline Jumlah & $\mathbf{7 8}$ & $\mathbf{1 0 0}$ \\
\hline
\end{tabular}

Berdasarkan Tabel 4.3 menunjukkan bahwa pekerjaan responden, dimana hasil penelitian menunjukkan bahwa dari 78 responden yang bekerja sebanyak 41 responden atau $(52.56 \%)$, dan yang tidak bekerja sebanyak 37 responden atau (47.44\%).

Tabel 4.4

\section{Distribusi Frekuensi Tingkat Pendidikan}

\begin{tabular}{|l|l|l|l|}
\hline No & Kategori & Frekuensi & Persentase (\%) \\
\hline 1 & Dasar & 29 & 37.18 \\
2 & Menengah & 34 & 43.59 \\
3 & Tinggi & 15 & 19.23 \\
\hline \multicolumn{2}{|c|}{ Jumlah } & $\mathbf{7 8}$ & $\mathbf{1 0 0}$ \\
\hline
\end{tabular}

Berdasarkan Tabel 4.4 menunjukkan bahwa pendidikan responden, dimana hasil penelitian menunjukkan bahwa dari 78 responden yang tingkat pendidikan dasar sebanyak 29

\subsection{Pembahasan}

\subsubsection{Variabel yang diteliti}

\subsubsection{Faktor Pengetahuan}

Pengetahuan adalah hasil pengindraan manusia, atau hasil tahu seseorang terhadap objek melalui indra yang dimilikinya (mata, hidung, telinga, dan sebagainya). Sebagian besar pengetahuan seseorang diperoleh melalui indra pendengaran (telinga), dan indra penglihatan (mata). Pengetahuan seseorang terhadap objek mempunyai intensitas atau tingkat yang berbeda-beda (Notoatmodjo, 2010). responden atau (37.18\%), yang tingkat pendidikan menengah sebanyak 34 responden atau (43.59\%), dan yang tingkat pendidikan tinggi sebanyak 15 responden atau (19.23\%).

Pengetahuan masyarakat tentang pentingnya ASI juga akan mempengaruhi pemberian ASI Eksklusif. Masyarakat yang tidak tahu menahu tentang pentingnya serta manfaat yang diberikan oleh ASI tidak akan memperdulikan hal tersebut

Hasil penelitian tingkat pengetahuan ibu menyusui tentang ASI eksklusif berdasarkan tabel 4.2 menunjukkan bahwa dari 78 responden yang memperoleh yang memperoleh kriteria baik sebanyak 20 responden atau (25.64\%), yang memperoleh kriteria cukup sebanyak 55 responden atau $(70.51 \%)$, dan yang mempunyai 
kriteria kurang sebanyak 3 responden atau $(3.85 \%)$.

Hasil penelitian ini bertolak belakang dengan teori yang ada yaitu menurut Damayanti, 2009 pengetahuan yang cukup akan memperbesar kemungkinan ibu untuk memberi ASI kepada bayinya.

\subsubsection{Faktor Pekerjaan}

Pekerjaan adalah sesuatu yang dilakukan manusia untuk tujuan tertentu yang dilakukan dengan cara yang baik dan benar. Pekerjaan sering disebut sebagai profesi (Sofiany : 2007).

Hasil penelitian tentang pekerjaan ibu menysui berdasarkan Tabel 4.3 menunjukkan bahwa pengetahuan responden tentang ASI Eksklusif, dimana hasil penelitian menunjukkan bahwa dari 78 responden yang memperoleh kriteria baik sebanyak 20 responden atau (25.64\%), yang memperoleh kriteria cukup sebanyak 55 responden atau (70.51\%), dan yang mempunyai kriteria kurang sebanyak 3 responden atau (3.85\%).

Sekarang banyak ibu yang bekerja untuk membantu perekonomian keluarga. Ketatnya aturan jam kerja, lokasi tempat tinggal yang jauh dari tempat kerja, ketiadaan fasilitas kenderaan pribadi kerap menjadi faktor yang menghambat ibu unuk memberikan ASI kepada bayinya. Tidak hanya itu, ibu yang bekerja secara fisik juga pasti akan cepat merasa kelelahan, sehingga merasa tidak punya tenaga lagi untu menyusui (Damayanti : 2009).

Hasil penelitian sesuai dengan teori yang ada yaitu menurut Khomsan, 2008, kesibukan karir merupakan salah satu penghambat utama seorang ibu dapat menyusui bayinya dengan sempurna.
4.3.1.3 Faktor Pendidikan

Pendidikan yang ditempuh oleh seseorang merupakan salah satu faktor demografi yang sangat berpengaruh terhadap kondisi kesehatan individu maupun masyarakat. (Kusmawati, 2006).

Hasil penelitian tentang tingkat pendidikan ibu menyusui berdasarkan Tabel 4.4 menunjukkan bahwa pendidikan responden, dimana hasil penelitian menunjukkan bahwa dari 78 responden yang tingkat pendidikan dasar sebanyak 29 responden atau (37.18\%), yang tingkat pendidikan menengah sebanyak 34 responden atau $(43.59 \%)$, dan yang tingkat pendidikan tinggi sebanyak 15 responden atau (19.23\%).

Tingkat pendidikan ibu umumnya terkait dengan pengetahuan. Secara umum ibu yang berpendidikan tinggi, pengetahuannya juga tinggi, dibandingkan dengan ibu-ibu yang berpendidikan rendah. Hal ini karena seorang ibu yang berpendidikan tinggi akan memiliki pengetahuan yang lebih luas serta kemampuan untuk menerima informasi lebih tinggi (Nazarina. 2008).

Hasil penelitian ini sesuai dengan teori yang ada yaitu menurut Partiwi, 2008, makin tinggi pendidikan seseorang, maka makin mudah untuk menerima informasi sehingga semakin banyak pula pengetahuan yang dimiliki. Sebaliknya pendidikan yang kurang atau menegah akan menghambat sikap terhadap nilai-nilai yang baru diperkenalkan, termasuk mengenai ASI Ekslusif.

\section{KESIMPULAN DAN SARAN Kesimpulan}

Dari penelitian yang telah dilakukan terhadap 78 responden dengan tingkat pengetahuan, pekerjaan dan 
pendidikan ibu menyusui dalam penghambat pemberian ASI eksklusif dapat diperoleh kesimpulan.

1. Tingkat pengetahuan ibu menyusui tentang pemberian ASI eksklusif di wilayah kerja Puskesmas Massenga dari 78 responden tersebut tingkat pengetahuan ibu menyusui berada pada kategori cukup yaitu 55 (70.51\%) responden.

2. Tingkat pekerjaan ibu menyusui dari 78 responden, tertinggi diperoleh pada kategori bekerja yaitu 41 (52.56\%) responden.

3. Tingkat pendidikan ibu menyusui dari 78 responden, tertinggi diperoleh pada kategori menengah yaitu $34(43.59 \%)$ responden.

\section{DAFTAR PUSTAKA}

Alimul, Aziz Hidayat. 2007. Metode Penelitian Kebidanan dan Teknik Analisis Data. Jakarta : Elex Media Komputindo

Arikunto, Suharsimi. 2006. Prosedur Penelitian. Jakarta : Rineka Cipta

Bahiyatun. 2009. Buku Ajar Asuhan Kebidanan Nifas Normal. Jakarta : Penerbit Buku Kedokteran ECG,

Damayanti, Diana. 2009. ASyik-nya Minum ASI. Jakarta : Penerbit PT.Gramedia Pustaka Utama

Hidayat. Alimul Aziz. 2007. Metode Penelitian Kebidanan dan Analisis Data. Jakarta : Salemba Medika
Khomsan, Ali,dkk. 2008. 50 Menu Sehat untuk Tumbuh Kembang Anak Usia6-24 bulan. Jakarta Selatan : PT. Agro Media Pustaka.

Kusrini. 2006. Sistem Pakar dan Teori Aplikasi. Yogyakarta : Penerbit C.V Andi Offset

Maryati, Kun., dkk. 2006. Sosiologi Jilid 2. jakarta : Penerbit Erlangga

Nazarina. 2008. Menu Sehat dan Aman untuk Bayi. Jakarta Selatan : Penerbit Hikmah

Nisman, Artanty Wenny. 2011. Panduan Pintar Ibu Menyusui. Yogyakarta : Penerbit C.V Andi

Notoadmodjo. 2007. Metode Penelitian Kesehatan. Jakarta : Rineka Cipta

Notoadmodjo. 2010. Metode Penelitian Kesehatan. Jakarta : Rineka Cipta

Nursalam. 2008. Konsep dan Penerapan Metodologi Pendelitian Ilmu Keperawatan. Jakarta : Salemba Medika.

Partiwi, Purwanti. Kendala Pemberian ASI Eksklusif, Bedah ASI. IDI DKI-BP FKUI ; Jakarta 2008. 
Pohon, Imbolo, S. 2007. Jaminan Mutu Layanan Kesehatan. Jakarta : Penerbit Buku Kedokteran ECG.

Priyono, Yunisa. 2010. Merawat bayi tanpa baby sitter. Yogyakarta : Media Pressindo

Raharjo, Handri. 2009. Hukum Perusahaan. Jakarta : Penerbit Pustaka Yustisia.

Rakyat, Dian. 2008. Menyusui Bayi Anda. PT. Dian Rakyat

Sofiany, Nila., dkk. 2007. Wahana Ilmu Pengetahuan Sosial. Jakarta : Penerbit Yudhistira

Sunarsih, Tri., dkk. 2011. Asuahan Kebidanan pada ibu nifas. Jakarta : Penerbit Salemba Medika

Tim pengembang ilmupendidikan FIF UPI. 2009.r Ilmu dan Aplikasi Pendidikan Cetakan Ketiga. Jakarta : PT. Imperial Bakti Utama

Wasis. 2008. Pedoman Riset Praktis untuk Profesi Perawat. Jakarta : Penerbit Buku Kedokteran ECG.

Yuliarti, Nurheti. 2010. Keajaiban Asi Makanan Terbaik untuk Kesehatan, Kecerdasan dan Kelincahan Si Kecil. Yogyakarta : Penerbit C.V Andi 